\title{
Oral Colon Delivery Platform Based on a Novel Combination Approach: Design Concept and Preliminary Evaluation
}

Saliha Moutaharrik ${ }^{\mathrm{a}}$, Alessandra Maronia ${ }^{*}$, Alice Melocchi ${ }^{\mathrm{a}}$, Lucia Zema ${ }^{\mathrm{a}}$, Anastasia Foppoli $^{\mathrm{a}}$, Matteo Cerea ${ }^{\mathrm{a}}$, Luca Palugan ${ }^{\mathrm{a}}$, Christel Neut ${ }^{\mathrm{b}}$, Florence Siepmann ${ }^{\mathrm{c}}$, Juergen Siepmann $^{\mathrm{c}}$, Andrea Gazzaniga ${ }^{\mathrm{a}}$

aSezione di Tecnologia e Legislazione Farmaceutiche "Maria Edvige Sangalli", Dipartimento di Scienze Farmaceutiche, Università degli Studi di Milano, 20133 Milano, Italy;

saliha.moutaharrik@unimi.it; alessandra.maroni@unimi.it; alice.melocchi@unimi.it;

lucia.zema@unimi.it; anastasia.foppoli@unimi.it; matteo.cerea@unimi.it; luca.palugan@unimi.it; andrea.gazzaniga@unimi.it.

bUniversity of Lille, Inserm, CHU Lille, UMR1286, F-59000 Lille, France; christel.neut@univ-lille.fr 'Université of Lille, Inserm, CHU Lille, U1008, F-59000 Lille, France; florence.siepmann@univlille.fr; juergen.siepmann@univ-lille.fr

"Corresponding author: alessandra.maroni@ unimi.it 


\section{ABSTRACT}

An oral colon delivery platform based on a novel combination strategy, leveraging multiple physiological characteristics of the intestine, is proposed. The system comprises a drug core, a waterswellable/soluble inner layer based on a hydrophilic cellulose derivative and an enteric outer layer (Eudragit ${ }^{\circledR} \mathrm{S}$ ) containing a microbially-degradable polysaccharide (high-amylose starch, Amylo N460), acting synergistically to prevent early release in the small intestine on the one hand, and release failure on the other. The Eudragit ${ }^{\circledR} \mathrm{S}$ : Amylo N460 solid weight ratio in the external coating was 7:3; triethyl citrate and glyceryl monostearate were used as plasticizer and anti-tacking agent, respectively. The outer Eudragit ${ }^{\circledR}$ S/Amylo N460 layer was applied in a fluid bed using hydroalcoholic or aqueous coating formulations. Two types of “inner” systems were studied: (i) Drugloaded tablets coated with a low-viscosity hydroxypropyl methylcellulose (by aqueous spray-coating), and (ii) hydroxypropyl cellulose capsules prepared by injection-molding (filled with paracetamol as an analytical tracer). The obtained dosage forms were thoroughly characterized, including in vitro release measurements in various media. In all cases, pulsatile release profiles were obtained after medium change from $0.1 \mathrm{~N} \mathrm{HCl}$ to phosphate buffer $\mathrm{pH} 7.4$, with lag phases depending on the type and preparation technique of the hydrophilic polymer layer. The role of the microbiota on the release performance was explored in simulated colonic fluid (SCF), consisting in culture medium inoculated with fecal samples from inflammatory bowel disease patients. Clear differences in drug release were observed in SCF versus culture medium free of feces, indicating the effect of microbial degradation.

\section{KEYWORDS}

Oral colon delivery; combined time-, $\mathrm{pH}$ - and microbiota-dependent approach; hydroxylpropyl methylcellulose; hydroxypropyl cellulose; Eudragit ${ }^{\circledR}$ S; high-amylose starch; spray-coating. 


\section{INTRODUCTION}

Targeted drug delivery to the colonic region of the gastrointestinal tract has received considerable attention in the last decades [1,2]. The scientific interest in this area has been driven by the need for a better treatment of local disorders of the colon, such as inflammatory bowel disease (IBD) including ulcerative colitis and Crohn's disease. The colon is also known as a possible gateway to the systemic circulation.

Over the past years, several strategies have been proposed for providing colon-targeted drug delivery, taking into account the physiological features of the intestine. Three major design strategies have been investigated, resulting in time-based, enzymatically-degradable and $\mathrm{pH}$-sensitive drug delivery systems [2].

The vast majority of commercially available products aiming at colonic drug delivery for the treatment of IBD is based on $\mathrm{pH}$-sensitive polymers, exploiting the $\mathrm{pH}$ changes along the gastrointestinal tract [3]. Enteric polymers are used, being insoluble at low pH (in the stomach) and becoming water-soluble at about neutral $\mathrm{pH}$. The systems are designed in such a way that the dissolution of the enteric polymer is sufficiently slow to delay the onset of drug release in the colon. Eudragit ${ }^{\circledR} \mathrm{S}$ (soluble at $\mathrm{pH}>7$ ), Eudragit $^{\circledR} \mathrm{L}$ (soluble at $\mathrm{pH}>5.5$ ), and Eudragit ${ }^{\circledR} \mathrm{FS}$ (soluble at $\mathrm{pH}>7$ ) (Evonik Industries) are most frequently employed. However, while the critical $\mathrm{pH}$ threshold of these polymers is often exceeded in the small intestine, it is typically not in the cecum and proximal colon [4,5]. Therefore, these systems may undergo premature release or release failure. In the first case, the drug is released before the colonic region is reached, while in the latter case, no release occurs at all and the delivery platform may be voided intact. $\gamma$-Scintigraphy studies of $\mathrm{pH}$-sensitive delivery systems have shown such erratic behavior in vivo [6-9]. To overcome the limitations associated with this approach, various strategies have been proposed. Schellekens and coworkers have developed a new delivery platform, which is based on a combination of Eudragit ${ }^{\circledR} \mathrm{S}$ and superdisintegrants, intended to ameliorate both the sitespecific delivery as well and the pulsatile release kinetics [10-12]. Another approach was based on the 
concept of a double coating, involving the application of two separate enteric layers: an inner one of partially neutralized polymer along with a buffer salt, and a standard enteric polymer layer as the outer coating. Liu et al. reported on an inner Eudragit ${ }^{\circledR} \mathrm{S}$ coating containing $10 \% \mathrm{KH}_{2} \mathrm{PO}_{4}$ (neutralized to $\mathrm{pH}$ 8.0), combined with a standard Eudragit ${ }^{\circledR} \mathrm{S}$ outer coating [13,14]. Drug release was found to be faster in $\mathrm{pH} 7.4$ physiological bicarbonate buffer (Krebs buffer) thanks to the buffer capacity of the inner coating. Furthermore, an especially innovative design concept based on a single coating layer composed of Eudragit ${ }^{\circledR} \mathrm{S}$ in admixture with a bacterially-degradable polysaccharide (resistant starch) was introduced [15-17]. In this case, the starch component undergoes degradation induced by the colonic microbiota and/or the enteric polymer dissolves. The fact that two release mechanisms are combined provides a backup in case of failure of one mechanism, e.g. if the dissolution threshold $\mathrm{pH}$ value is not reached, the degradation of starch still assures drug release in the colon. This type of delivery systems was tested in healthy volunteers to assess the site of disintegration, which was consistently seen at the ileocecal junction or in the proximal large intestine [15]. However, in spite of the increased chances to avoid failure of drug release in the large bowel, the risk of premature release into the small intestine is still not fully addressed.

Based on these premises, the present work was focused on the design, manufacturing and evaluation of a novel oral colon delivery platform based on a combined strategy addressing both issues at the same time: release failure and premature release. Accordingly, a two-layer system was proposed, wherein a swellable/erodible polymer barrier was present beneath an enteric coating containing high-amylose starch, so that the drug core is protected during an additional period of time in case the outer coat dissolves before the colonic region is reached [18-20]. The swellable polymeric layer, based on a hydrophilic cellulose derivative, consisted in either a coating applied to a tablet core or a capsule shell manufactured by injection-molding. Capsules are particularly of interest, since they can be filled with a variety of drug formulations, drug release being governed by the shell [21]. Moreover, the use of injection-molding offers considerable advantages in terms of solvent-free processing, versatility and potential suitability for continuous manufacturing [22]. 


\section{MATERIALS AND METHODS}

\subsection{MATERIALS}

Paracetamol for direct compression (Rhodapap ${ }^{\mathrm{TM}}$ DC 90, Novacyl, Lyon, France), microcrystalline cellulose (Avicel ${ }^{\circledR}$ PH-101, FMC Corporation, San Colombano al Lambro, Italy), sodium starch glycolate (Explotab ${ }^{\circledR}$ CLV, JRS PHARMA, Castenedolo, Italy), vinylpyrrolidone-vinyl acetate copolymer (Kollidon ${ }^{\circledR}$ VA 64, BASF Italia Spa, Cesano Maderno, Italy), hydrophilic fumed silica (Aerosil $^{\circledR}$ 200, Evonik Degussa Italia Spa, Pandino, Italy), magnesium stearate (Recordati Spa, Milan, Italy), hydroxypropyl cellulose (HPC, Klucel $^{\mathrm{TM}}$ LF, Eigenmann \& Veronelli Spa, Rho, Italy), polyethylene glycol (PEG 400 and 1500, Clariant SE, Sulzbach am Taunus, Germany), hydroxypropyl methylcellulose (HPMC, Methoce ${ }^{\circledR}$ E50, Colorcon, Dartford, Kent, United Kingdom), methacrylic acid-methyl methacrylate copolymer (1:2) $\left(\right.$ Eudragit $^{\circledR}$ S, Evonik Degussa Italia Spa, Pandino, Italy; EuS), high-amylose corn starch (Amylo N460, Roquette Frères, Cassano Spinola, Italy; Amylo), triethyl citrate (TEC, Honeywell International Inc, Charlotte, North Carolina, US), glyceryl monostearate (GMS, Gattefossé S.A., Saint-Priest, France), polysorbate 80 (Tween 80, ACEF Spa, Fiorenzuola d'Arda, Italy), ammonia solution 25 \% v/v (Carlo Erba Reagents Srl, Cornaredo, Italy) 1butanol (Fisher Scientific Italia, Rodano, Italy), ethanol 96 (VWR International Srl, Milan, Italy).

\subsection{METHODS}

\subsubsection{Manufacturing of delivery systems}

Tablets: Paracetamol DC (80 \%), Avicel ${ }^{\circledR}$ PH 101 (12.5\%), Explotab ${ }^{\circledR}$ CLV (4.5\%), Kollidon ${ }^{\circledR}$ VA $64(2.0 \%)$, Aerosil $^{\circledR} 200(0.5 \%)$ and magnesium stearate $(0.5 \%)$ powders were blended in a Turbula mixer (Willy A. Bachofen AG, Muttenz 1, Switzerland; $12+3$ min, 200 rpm) . The blend was compressed using a rotary press (AM-8S, Officine Meccaniche f.lli Ronchi, Cinisello Balsamo, Italy), equipped with concave punches ( $4 \mathrm{~mm}$ diameter, $4 \mathrm{~mm}$ curvature radius). The tablets (40 $\mathrm{mg}$ nominal 
weight) were characterized with respect to their weight (analytical balance BP211D Sartorius Italy Srl, Varedo, Italy; n=20), friability (friabilometer TA3R Erweka GmbH, Langen, Germany), crushing strength (crushing tester TBH30 Erweka GmbH, Langen, Germany; n=10), height and diameter (digital micrometer, Mitutoyo Italiana Srl, Lainate, Italy; $\mathrm{n=20)}$ and disintegration time (three-position disintegration apparatus DT3 Sotax Srl, Milan, Italy; n=6). The weight, height, diameter, crushing strength (mean \pm s.d.), friability and disintegration time were $40.26 \pm 1.31 \mathrm{mg}, 3.15 \pm 0.04 \mathrm{~mm}, 4.02 \pm$ $0.01 \mathrm{~mm}, 43.2 \pm 4.8 \mathrm{~N},<1 \%$ and $<5$ min, respectively.

Capsule shells: HPC was oven-dried at $40{ }^{\circ} \mathrm{C}$ for $24 \mathrm{~h}$ and blended with PEG $1500(9: 1 \mathrm{w} / \mathrm{w})$. The mixture was introduced into a bench-top micromolding machine (BabyPlast 6/10P, Cronoplast S.L., Barcelona, Spain), equipped with capsule shell-shaped molds (caps and bodies) [23]. The nominal weight and thickness of the capsule shells were $230 \mathrm{mg}$ and $600 \mu \mathrm{m}$, respectively. The capsules were manually filled with paracetamol DC (130 mg). Their key properties were as follows: weight $=356.06$ $\pm 4.30 \mathrm{mg}$, height $=13.15 \pm 0.17 \mathrm{~mm}$, diameter of caps $=8.05 \pm 0.04 \mathrm{~mm}$, diameter of bodies $=8.07 \pm$ 0.05 mm (mean \pm s.d.; $\mathrm{n}=20)$.

Coating: Tablets were coated with an aqueous solution of HPMC (8\% w/w + $10 \%$ PEG 400, based on the dry polymer mass) in a tangential-spray fluid bed (Glatt GPCG 1.1, Glatt GmbH, Binzen, Germany) [24]. HPMC-coated tablets and injection-molded HPC capsules (filled with paracetamol) were coated with Eudragit ${ }^{\circledR} S$ in admixture with high-amylose starch using a bench-top bottom-spray fluid bed apparatus (Mini-Glatt, Glatt GmbH, Binzen, Germany) and a pan-coater (GS Coating Technologies Srl, Castel San Pietro Terme, Italy; pan of 1 L capacity), respectively. The coating formulations and process parameters used are reported in the Results and Discussion section. In all cases, the Eudragit ${ }^{\circledR}$ S : Amylo N460 (weight : weight) ratio was 7:3, and TEC and GMS were added as plasticizing and anti-tacking agents, respectively.

In case of hydro-alcoholic coatings, Eudragit ${ }^{\circledR} \mathrm{S}$ was dissolved at $6 \% \mathrm{w} / \mathrm{w}$ in ethanol $96^{\circ}$ under magnetic stirring. Amylo N460 was dispersed in 1-butanol, and distilled water was added under 
magnetic stirring [25]. The final concentration of high-amylose starch was $4 \% \mathrm{w} / \mathrm{w}$, and the 1butanol/water weight ratio was 1:11. This dispersion was heated, kept boiling for $30 \mathrm{~min}$ and then left cooling at room temperature overnight. Subsequently, the alcoholic Eudragit ${ }^{\circledR}$ S solution was slowly mixed with the Amylo N460 formulation under magnetic stirring. After 2 h, TEC (10\% or $20 \%$ w/w, based on the dry Eudragit ${ }^{\circledR} \mathrm{S}$ and Amylo N460 mass) and a fine $5 \%$ w/w GMS suspension (5 \% w/w, based on the dry Eudragit ${ }^{\circledR} \mathrm{S}$ and Amylo N460 mass) were incorporated and the resulting dispersion was stirred for $2 \mathrm{~h}$ before coating. The GMS suspension was prepared as follows: GMS was suspended in an aqueous polysorbate 80 (40\% w/w, based on the dry GMS mass) solution under vigorous mixing and heated to $75^{\circ} \mathrm{C}$ for 15 min prior to use.

In case of aqueous coatings, Eudragit ${ }^{\circledR} \mathrm{S}$ was dispersed in distilled water at a concentration of $21.4 \%$ w/w. An ammonia solution ( $1 \mathrm{~N})$ was added dropwise up to $15 \%$ theoretical neutralization of the polymethacrylate under magnetic stirring. After $1 \mathrm{~h}$, TEC (49\% w/w, based on the dry polymer mass) and the fine $5 \% \mathrm{w} / \mathrm{w}$ GMS suspension ( $7 \% \mathrm{w} / \mathrm{w}$, based on the dry polymer mass) were incorporated into the polymethacrylate dispersion and stirred for $1 \mathrm{~h}$. Amylo N460 was suspended in distilled water at $4 \% \mathrm{w} / \mathrm{w}$ under magnetic stirring [26-28]. The resulting dispersion was heated, kept boiling for 30 min and then left cooling at room temperature overnight. Finally, the aqueous suspension of Eudragit ${ }^{\circledR}$ S, TEC and GMS was slowly mixed with the Amylo N460 dispersion under magnetic stirring. After coating, all units were oven-cured at $40{ }^{\circ} \mathrm{C}$ for 24 or $48 \mathrm{~h}$.

\subsubsection{Characterization of the delivery systems}

Physical characterization: The weight gain (\%) was determined as follows:

Weight gain $(\%)=\frac{\bar{m}_{\text {coated units }}-\bar{m}_{\text {core units }}}{\bar{m}_{\text {core units }}} \times 100$ Eq. 1 where $\bar{m}$ is the average weight of coated or core units $(n=100)$.

The amount of coating material per unit surface area $\left(\mathrm{mg} / \mathrm{cm}^{2}\right)$ was calculated, considering the following surfaces:

Tablet surface $=4 \pi(\mathrm{R}-\mathrm{r})\left(\mathrm{R}-\sqrt[2]{\mathrm{R}^{2}-\mathrm{r}^{2}}\right)+2 \pi r h_{c p r}$ Eq. 2 
$\begin{array}{ll}\text { Capsule surface }=2 \pi c^{2}+\pi \mathrm{b}\left(\mathrm{c}+2 \mathrm{~b}+h_{\text {cps }}\right) & \text { Eq. } 3\end{array}$

where $\mathrm{R}, \mathrm{r}$ and $\mathrm{h}_{\mathrm{cpr}}$ are the curvature radius, radius and height of tablets; $\mathrm{c}, \mathrm{b}$ and $\mathrm{h}_{\mathrm{cps}}$ are the radius of caps, radius of bodies and height of the capsules. Mean values \pm standard deviation are indicated $(\mathrm{n}=$ 100).

The thickness of the applied coatings and capsule shells was measured using a digital microscope (Dyno-Lite Pro AM-413T, AnMo Electronics Corporation, Hsinchu 300, Taiwan). Mean values \pm standard deviation are reported of 30 measurements (10 different regions in 3 cross-sections).

The morphology of cross-sections of coated tablets and capsules was analyzed using a scanning electron microscope (SEM, VEGA-TS5136 XM, Tescan Analytics, BrnoKohoutovice, Czech Republic) after gold-sputtering in a plasma evaporator under Argon flow (Sputter coater, Edwards, S150B, West Sussex, United Kingdom; 1 kV, 40 mA; 1 min). Photomicrographs were acquired at an accelerated voltage of $20 \mathrm{kV}$, using a magnification of 100x or 500x. SEM images were also used to randomly confirm the coating and shell thickness measurements described above.

In vitro drug release in $\mathrm{HCl}$ and phosphate buffer: Paracetamol release from coated tablets and capsules was determined using the USP 43 paddle apparatus (Dissolution System 2100B, Distek Strumenti \& Misure srl, Napoli, Italy; 100 rpm) and a modified USP 43 disintegration apparatus (Sotax DT3, Sotax Srl, Milano, Italy; 31 cycles/min) [23,29], respectively. In both cases, the release medium $\left(37 \pm 0.5^{\circ} \mathrm{C}\right)$ was $800 \mathrm{~mL} 0.1 \mathrm{~N} \mathrm{HCl}$ for the first $2 \mathrm{~h}$, followed by phosphate buffer (PB) $\mathrm{pH}$ 7.4. Samples were automatically withdrawn at pre-determined time points. Their drug content was measured by UV spectrophotometry at $\lambda=248 \mathrm{~nm}$. If indicated, drug release was also measured after storage for 12 months at $25 \pm 2 \mathrm{C}$ and $60 \pm 5 \%$ relative humidity (RH) in closed polyethylene bags. Mean values \pm standard deviation are reported $(n=3)$.

In vitro drug release in simulated colonic fluid: Coated tablets and capsules were first exposed to 0.1 $\mathrm{N} \mathrm{HCl}$ for $2 \mathrm{~h}$, followed by $2 \mathrm{~h}$ in phosphate buffer $\mathrm{pH} 4.5$ using the USP 43 dissolution paddle apparatus (100 rpm, $800 \mathrm{~mL}$ ) and a BioDis dissolution tester (Varian, Paris, France; $10 \mathrm{dpm}, 200 \mathrm{~mL}$ ), respectively. The systems were then transferred into $120 \mathrm{~mL}$ flasks containing culture medium (CM) 
inoculated with fecal samples collected from IBD patients as "simulated colonic fluid (SCF)" [26,2931]. For reasons of comparison, drug release was also measured in pure culture medium. The latter was prepared as follows: $1.5 \mathrm{~g}$ beef extract, $3 \mathrm{~g}$ yeast extract, $5 \mathrm{~g}$ tryptone, $2.5 \mathrm{~g} \mathrm{NaCl}$, and $0.3 \mathrm{~g} \mathrm{~L}$ cysteine hydrochloride hydrate were dissolved in $1 \mathrm{~L}$ distilled water $(\mathrm{pH} 6.5 \pm 0.2)$. The resulting solution was sterilized in an autoclave prior to use. SCF consisted of $100 \mathrm{~mL}$ of CM inoculated with 1 $\mathrm{g}$ of fecal residues, incubated under anaerobic conditions at $37^{\circ} \mathrm{C}$ and horizontally shaken $(50 \mathrm{rpm})$ for $20 \mathrm{~h}$. At programmed time points, $2 \mathrm{~mL}$ fluid samples were withdrawn, centrifuged $(13,000 \mathrm{rpm}, 5$ min) and filtered $(0.22 \mu \mathrm{m})$ before drug content determination by HPLC analysis (ThermoFisher Scientific Ultimate 3000, US-MA). A Gemini ${ }^{\circledR} 5 \mu \mathrm{m} \mathrm{C18} 110 \AA$, 150×4.6 mm column (Phenomenex, UK) was used. Ten $\mu \mathrm{L}$ samples were injected, and the flow rate was set at $1 \mathrm{~mL} / \mathrm{min}$. The mobile phase consisted of blends of: (A) water adjusted to $\mathrm{pH} 2$ with orthophosphoric acid and (B) acetonitrile. The following gradient program was used: 0-10 min: 5-20 \% B; 10-11 min: 20-5 \% B [32]. Paracetamol was detected UV spectrophotometrically at $\lambda=248 \mathrm{~nm}$. Mean values \pm standard deviation are reported $(n=3)$.

\section{RESULTS AND DISCUSSION}

A novel drug delivery platform is proposed, consisting of a drug-containing core, surrounded by a swellable/soluble polymer layer and a second (outer) Eudragit ${ }^{\circledR}$ S-based film, into which high-amylose starch is incorporated as a microbially-degradable polysaccharide. The outer coating is intended to protect the system during transit throughout the proximal gastrointestinal tract. The naturallyoccurring polysaccharide is expected to act as a site-specific release trigger following degradation by the colonic microbiota, enabling drug release, even if the system has not been exposed for a sufficient time lapse to $\mathrm{pH}$ values above the dissolution threshold of the gastroresistant polymer. The internal polymer layer is intended to protect the drug core for an additional time period in case the outer coating does not reach the colonic region intact. Thus, multiple release control mechanisms, based on a combination of major physiological variables, were leveraged in order to limit the likelihood of both premature release and release failure. 
The coating level of the Eudragit ${ }^{\circledR}$ S/Amylo N460 film, expressed as amount of polymethacrylate per unit area for comparison purposes, was set at approximately $7 \mathrm{mg} / \mathrm{cm}^{2}$ based on literature findings, whereas two different nominal thicknesses were studied for the HPMC layer: 100 and $200 \mu \mathrm{m}$ [25]. The outer Eudragit ${ }^{\circledR}$ S/Amylo N460 layer was applied onto tablets coated with low-viscosity HPMC or injection-molded HPC capsules. Both the HPMC-coated tablets and the injection-molded HPC capsules were designed to provide time-controlled release with a pre-programmed lag phase $[22,23,33,34]$. The Eudragit ${ }^{\circledR}$ S/Amylo N460 coatings were applied from either hydro-alcoholic or aqueous coating formulations. In the case of the hydro-alcoholic formulation, two different TEC percentages (10 and $20 \% \mathrm{w} / \mathrm{w}$, based on the dry polymer mass) were evaluated (Table I). In the case of the aqueous coating formulation, $49 \%$ TEC (w/w, based on the dry polymer mass) was added. Also, a preliminarily study was carried out with tablets, omitting the inner HPMC coating to investigate the effects of different curing times and assure long-term stability [35].

The coating processes were successfully carried out using the equipment and operating conditions reported in Table II. 
Table I: Compositions of the investigated coating formulations. Amounts are indicated in $\% \mathrm{w} / \mathrm{w}$.

\begin{tabular}{|c|c|c|c|}
\hline Components & $\begin{array}{c}\text { Eudragit }^{\circledR} \text { S/Amylo N460 } \\
\text { coating } \\
\text { Hydro-alcoholic } \\
10 \% \text { TEC }\end{array}$ & $\begin{array}{c}\text { Eudragit }^{\circledR} \text { S/Amylo N460 } \\
\text { coating } \\
\text { Hydro-alcoholic } \\
20 \% \text { TEC }\end{array}$ & $\begin{array}{c}\text { Eudragit }^{\circledR} \text { S/Amylo N460 } \\
\text { coating } \\
\text { Aqueous } \\
49 \% \text { TEC }\end{array}$ \\
\hline Eudragit $^{\circledR} S$ & 3.45 & 3.44 & 5.38 \\
\hline Amylo N460 & 1.48 & 1.47 & 2.31 \\
\hline Triethyl citrate & 0.49 & 0.98 & 3.76 \\
\hline Glyceryl monostearate & 0.25 & 0.25 & 0.54 \\
\hline Tween $^{\circledR} 80$ & 0.10 & 0.10 & 0.21 \\
\hline $\mathrm{NH} 31 \mathrm{~N}$ & - & - & 2.69 \\
\hline 1-Butanol & 2.96 & 2.95 & - \\
\hline Ethanol $\left(96^{\circ}\right)$ & 54.11 & 53.85 & - \\
\hline Distilled water & 36.97 & 36.97 & 85.11 \\
\hline
\end{tabular}


Table II: Equipment and process parameters used

\begin{tabular}{|c|c|c|c|c|c|}
\hline \multirow[b]{2}{*}{ Equipment } & \multirow{2}{*}{$\begin{array}{c}\text { HPMC coating } \\
\text { Tangential-spray fluid bed }\end{array}$} & \multicolumn{2}{|c|}{$\begin{array}{c}\text { Eudragit }^{\circledR} \text { S/Amylo N460 coating } \\
\text { Hydro-alcoholic }\end{array}$} & \multicolumn{2}{|c|}{$\begin{array}{c}\text { Eudragit }^{\circledR} \text { S/Amylo N460 coating } \\
\text { Aqueous }\end{array}$} \\
\hline & & Bottom-spray fluid bed & Coating pan & Bottom-spray fluid bed & Coating pan \\
\hline Core & Tablets & Tablets & HPC capsules & Tablets & HPC capsules \\
\hline Nozzle pore size $(\mathrm{mm})$ & 1.2 & 0.5 & 0.8 & 0.5 & 0.8 \\
\hline Atomizing air pressure (bar) & 2 & 0.2 & 0.2 & 0.2 & 0.25 \\
\hline Pattern air pressure (bar) & - & - & 0.2 & - & 0.35 \\
\hline Drying air volume $\left(\mathrm{m}^{3} / \mathrm{h}\right)$ & 100 & 40 & 32 & $34-40$ & 32 \\
\hline Inlet air temperature $\left({ }^{\circ} \mathrm{C}\right)$ & 59 & 40 & 40 & 42 & $59-63$ \\
\hline Outlet air temperature $\left({ }^{\circ} \mathrm{C}\right)$ & 53 & - & - & - & - \\
\hline Product temperature $\left({ }^{\circ} \mathrm{C}\right)$ & 52 & $30-32$ & $21-24$ & $26-28$ & $30-32$ \\
\hline Spray rate $(\mathrm{g} / \mathrm{min} / \mathrm{kg})$ & $3-5$ & $12-18$ & $22-26$ & $28-29$ & $24-25$ \\
\hline Post drying time (min) & 30 & 10 & 5 & 5 & 5 \\
\hline
\end{tabular}


Importantly, curing for $24 \mathrm{~h}$ at $40{ }^{\circ} \mathrm{C}$ was found to be sufficient to provide long-term stable coatings: Figure 1 shows release of paracetamol, used as an analytical tracer, in 0.1 $\mathrm{N} \mathrm{HCl}$ for $2 \mathrm{~h}$, followed by phosphate buffer $\mathrm{pH} 7.4$ from tablets coated with an aqueous dispersion of Eudragit ${ }^{\circledR}$ S/Amylo N460 . As can be seen, release was very similar before and after 12 months storage at $25 \pm 2{ }^{\circ} \mathrm{C}$ and $60 \pm 5 \% \mathrm{RH}$, upon curing for 24 or $48 \mathrm{~h}$ at $40{ }^{\circ} \mathrm{C}$.

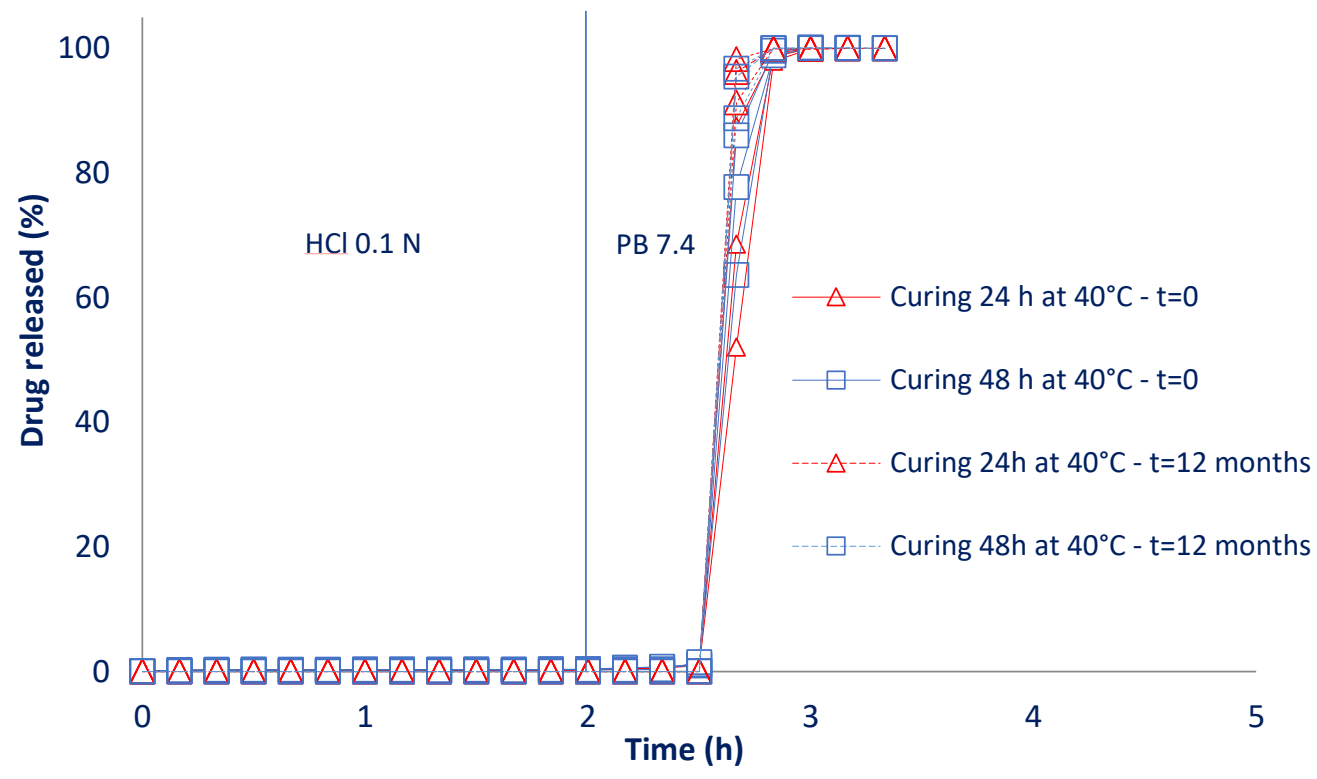

Figure 1: Paracetamol release from tablets coated with an Eudragit $t^{\circledR}$ S/Amylo N460 layer applied from an aqueous dispersion. The tablets were cured for 24 or $48 \mathrm{~h}$ at $40^{\circ} \mathrm{C}$. Drug release is shown before and after 12 months at $25 \pm 2{ }^{\circ} \mathrm{C}$ and $60 \pm 5 \% \mathrm{RH}$.

The obtained coated tablets had a smooth outer surface and key physical properties listed in Table III. Cross-sections were analyzed by SEM, indicating good film coating quality. Differences were highlighted between Eudragit ${ }^{\circledR}$ S/Amylo N460 films applied from hydroalcoholic (20\% TEC) versus aqueous (49\% TEC) formulations (Figure 2). Indeed, the 
latter displayed signs of a less continuous structure, as could be expected based on the type of coating formulation (containing polymer particles), in sharp contrast to the underlying cellulosic layer. On the other hand, in the case of the hydro-alcoholic Eudragit ${ }^{\circledR}$ S/Amylo N460 coating formulation, a boundary between the inner and outer coatings could hardly be seen. This might be explained by the fact that both Eudragit ${ }^{\circledR} \mathrm{S}$ and HPMC are dissolved in their respective coating formulations, leading to more homogeneous appearance of the resulting layers. Moreover, polymer-polymer entanglement may occur at the interface because HPMC can hydrate and dissolve following exposure to the ethanol/water mixture when the Eudragit ${ }^{\circledR}$ S/Amylo N460 film is applied. 
Table III: Key physical properties of the investigated systems

\begin{tabular}{|c|c|c|c|c|c|c|}
\hline \multirow[b]{2}{*}{ Core } & \multirow[b]{2}{*}{ Batch code } & \multicolumn{2}{|c|}{ Inner coating/Shell } & \multicolumn{3}{|c|}{ Outer coating } \\
\hline & & $\begin{array}{l}\text { Amount per unit area } \\
\left(\mathrm{mg} / \mathrm{cm}^{2}\right)\end{array}$ & $\begin{array}{c}\text { Thickness } \\
(\mu \mathrm{m})\end{array}$ & $\begin{array}{c}\text { Total amount applied } \\
\left(\mathrm{mg} / \mathrm{cm}^{2}\right)\end{array}$ & $\begin{array}{c}\text { Eudragit }^{\circledR} \text { S amount applied } \\
\left(\mathrm{mg} / \mathrm{cm}^{2}\right)\end{array}$ & $\begin{array}{l}\text { Thickness } \\
(\mu \mathrm{m})\end{array}$ \\
\hline \multirow{9}{*}{ Tablets } & HPMC0-EuS/AmyloW/ETEC10 & - & - & 11.9 & 7.1 & $86.7 \pm 7.4$ \\
\hline & HPMC100-EuS/AmyloW/E & 13.3 & $110.5 \pm 4.2$ & 12.0 & 7.2 & $80.3 \pm 4.8$ \\
\hline & HPMC200-EuS/AmyloW/ETEC10 & 27.7 & $220.4 \pm 5.9$ & 12.6 & 7.5 & $82.3 \pm 4.1$ \\
\hline & HPMC0-EuS/AmyloW/ETEC20 & - & - & 13.1 & 7.2 & $97.8 \pm 5.4$ \\
\hline & HPMC100-EuS/AmyloW/E & 13.3 & $110.5 \pm 4.2$ & 12.2 & 6.7 & $91.9 \pm 2.8$ \\
\hline & HPMC200-EuS/AmyloW/ETEC20 & 27.7 & $220.4 \pm 5.9$ & 11.7 & 6.4 & $87.0 \pm 4.7$ \\
\hline & HPMC0-EuS/AmyloW TEC49 & - & - & 17.7 & 7.8 & $125.5 \pm 7.2$ \\
\hline & HPMC100-EuS/AmyloW TEC49 & 13.3 & $110.5 \pm 4.2$ & 16.2 & 7.1 & $128.3 \pm 7.0$ \\
\hline & HPMC200-EuS/AmyloW ${ }_{\text {TEC49 }}$ & 27.7 & $220.4 \pm 5.9$ & 16.3 & 7.2 & $117.5 \pm 11.0$ \\
\hline \multirow{2}{*}{ Capsules } & HPC-EuS/AmyloW/E & 68.8 & $603.1 \pm 6.2$ & 13.2 & 7.3 & $130.8 \pm 5.8$ \\
\hline & HPC-EuS/AmyloW ${ }_{\mathrm{TEC} 49}$ & 68.8 & $603.1 \pm 6.2$ & 18.0 & 7.9 & $133.9 \pm 10.6$ \\
\hline
\end{tabular}



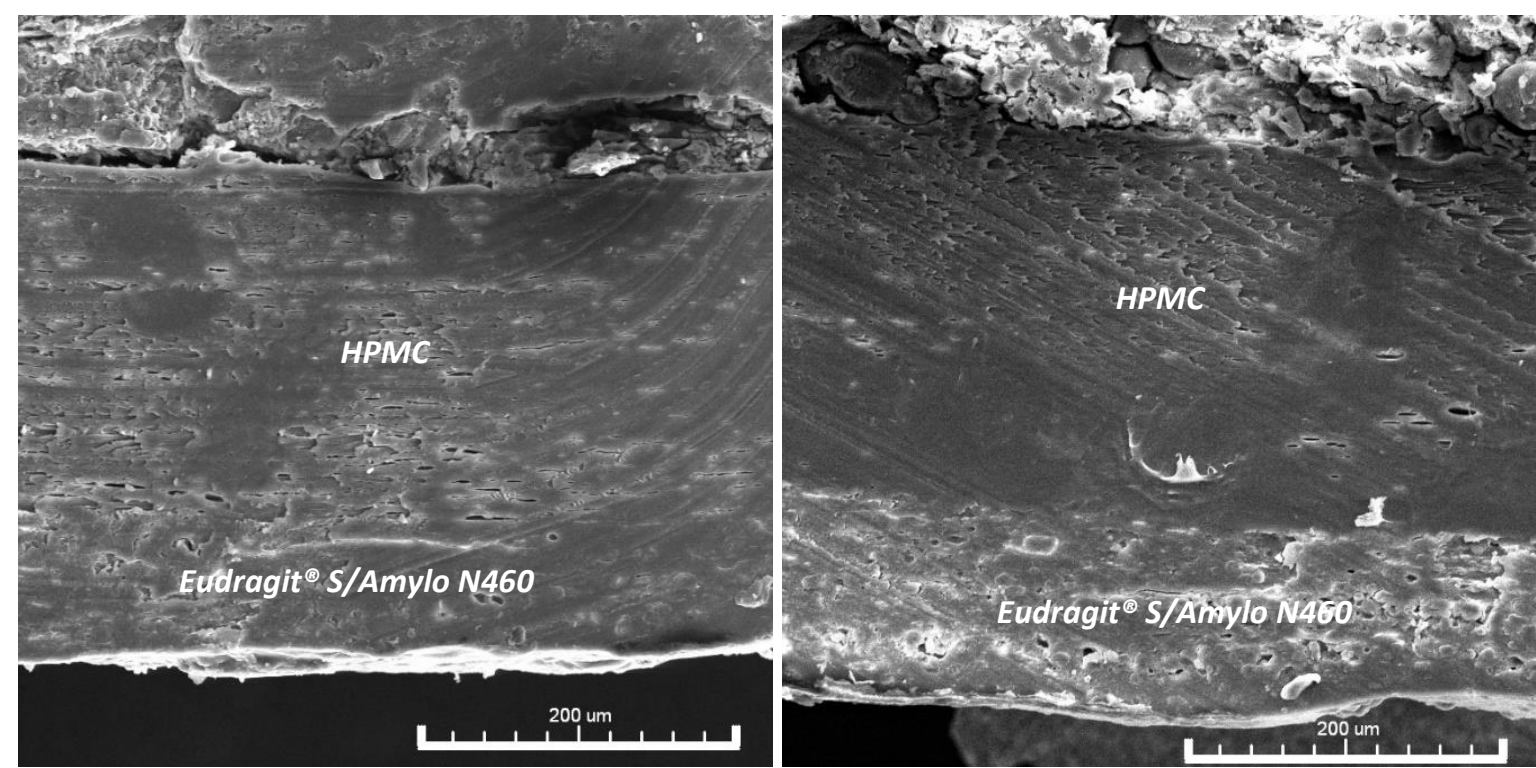

Figure 2: SEM photomicrographs of cross-sections of paracetamol tablets coated with an inner HPMC layer and an outer Eudragit ${ }^{\circledR}$ S/Amylo N460 layer. The latter was applied from a hydro-alcoholic coating formulation (containing $20 \%$ TEC, based on the dry polymer mass) (left), or from an aqueous_coating formulation (containing $49 \%$ TEC, based on the dry polymer mass) (right).

The release of paracetamol from the differently coated formulations was monitored in vitro. All systems, irrespective of the presence or absence of the inner HPMC layer, proved to withstand $2 \mathrm{~h}$ exposure to $0.1 \mathrm{~N} \mathrm{HCl}$, without noteworthy drug release, indicating gastroresistance according to compendial requirements (Figure 3a-c). After medium change to phosphate buffer $\mathrm{pH} 7.4$, pulsatile release profiles were observed. Importantly, the presence of the inner HPMC layer prolonged the lag time as a function of its thickness. In the case of the hydro-alcoholic coating formulations, an increase in the amount of TEC seemed to shorten the lag time in the absence of the inner HPMC layer. This might be explained by the leaching of the water-soluble plasticizer into the release medium. The presence of the inner HPMC coating seems to make the system more robust, reducing the impact of this phenomenon on drug release. 
(a)

Hydro-alcoholic, $10 \%$ TEC

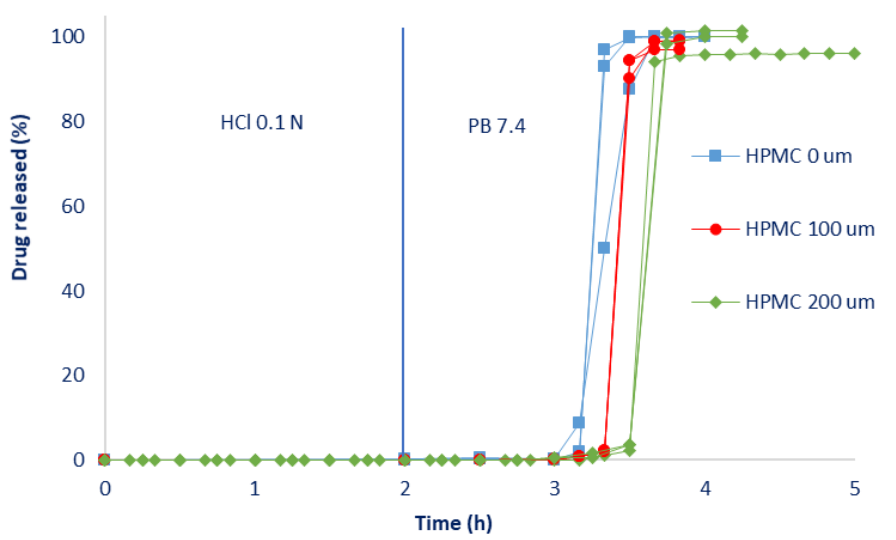

(b)

Hydro-alcoholic, $20 \%$ TEC

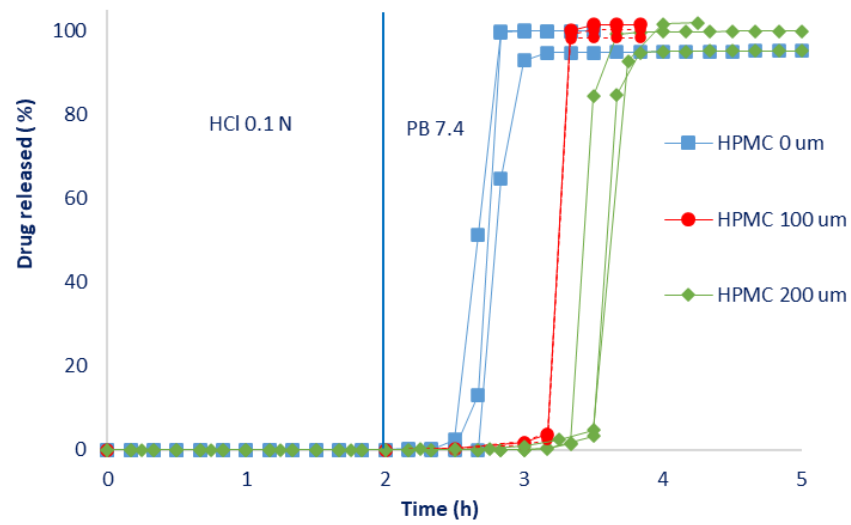

(c)

Aqueous, $49 \%$ TEC

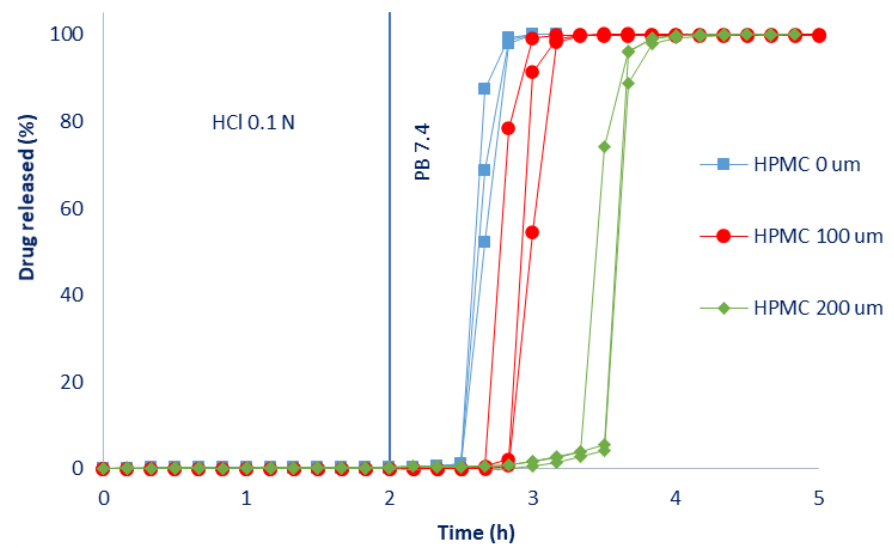

Figure 3: Paracetamol release from tablets coated with an outer Eudragit ${ }^{\circledR}$ S/Amylo N460 layer, containing $10 \%$ TEC (a), $20 \%$ TEC (b), or $49 \%$ TEC (c), applied from a hydro-alcoholic $(a, b)$ or aqueous $(c)$ coating formulation. The tablet cores were optionally coated with a 100 or 200 um thick HPMC layer.

Based on these results, both the hydro-alcoholic and aqueous coating formulations were considered promising also for application onto injection-molded HPC capsules filled with paracetamol aiming at pulsatile release. In the case of hydro-alcoholic spray-coating, the formulation containing a higher amount of TEC was preferred. As opposed to tablets, which were coated in a bottom-spray fluid bed, pan-coating was chosen for capsules due to their larger size. Using the operating conditions listed in Table II, the coating process 
proved to be feasible, in spite of the critical mass and shape characteristics of the capsules, possibly leading to irregular motion patterns. Moreover, no deformation phenomena, such as shrinking and expansion of the polymeric shells, were observed (Figure 4).

The coating obtained when applying the hydro-alcoholic Eudragit ${ }^{\circledR}$ S/Amylo N460 dispersion (plasticized with $20 \%$ TEC) onto HPC capsules was evaluated by SEM analysis. The image on the left-hand side of Figure 5 reveals a homogenous thickness and dense structure of the polymeric layer. As in the case of the HPMC-coated tablets, the polymethacrylate/polysaccharide coating adhered well onto the HPC shell, despite the diverse substrates and coating equipment used (rotating pan $v s$. bottom-spray fluid bed). Please note that also in the case of the HPC capsules, structural differences were observed in the Eudragit ${ }^{\circledR}$ S/Amylo N460 coatings applied from the hydro-alcoholic formulation (20 $\%$ TEC) versus aqueous dispersion (49\% TEC).

Both hydro-alcoholic and aqueous coatings provided prompt and quantitative release in phosphate buffer $\mathrm{pH} 7.4$ after reproducible lag times, which can be attributed to the polymethacrylate/polysaccharide coating as well as to the swellable/erodible injectionmolded HPC shell (Figure 6). The lag phase was longer in the case of the hydro-alcoholic coating formulation, which is in good agreement with the denser and more homogeneous inner structure of the films (please see above). Compared to uncoated capsules [21], the Eudragit ${ }^{\circledR}$ S/Amylo N460 coated formulations showed an approximately 2 and 4-fold longer lag phase after medium change from $0.1 \mathrm{~N} \mathrm{HCl}$ to phosphate buffer $\mathrm{pH} 7.4$ in the case of aqueous and hydro-alcoholic coating formulations, respectively. These results demonstrate the suitability of the proposed aqueous and hydro-alcoholic formulations for 
the coating of capsules and the quality of the processes. Importantly, in all cases, the original pulsatile release profile of the uncoated HPC capsule was preserved.

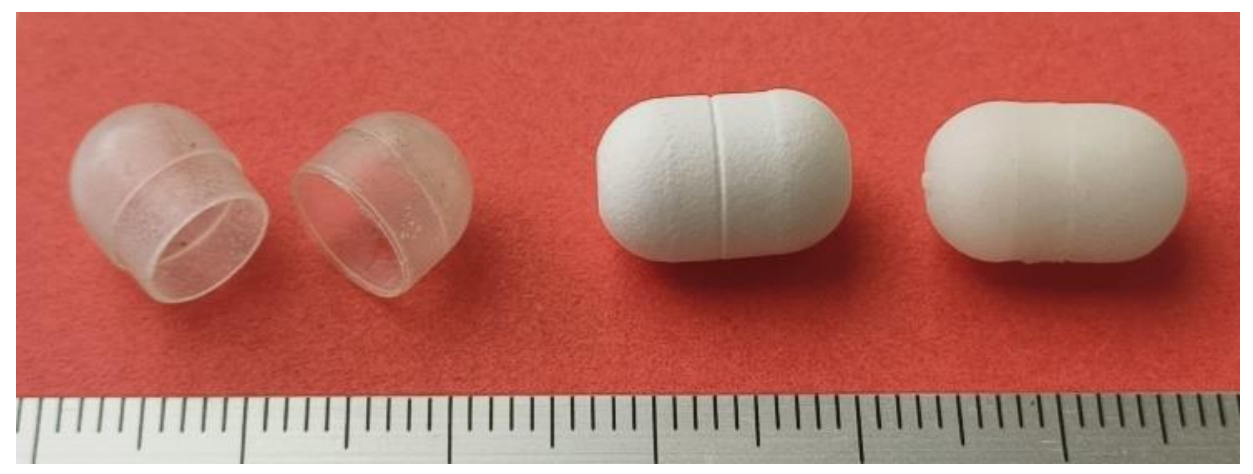

Figure 4: Photographs of empty HPC capsule shells (left) and HPC capsules coated with a Eudragit ${ }^{\circledR}$ S/Amylo N460 layer applied from a hydro-alcoholic (20\% TEC) (middle) or an aqueous (49\% TEC) (right) coating formulation. The scale bar is in $\mathrm{mm}$.
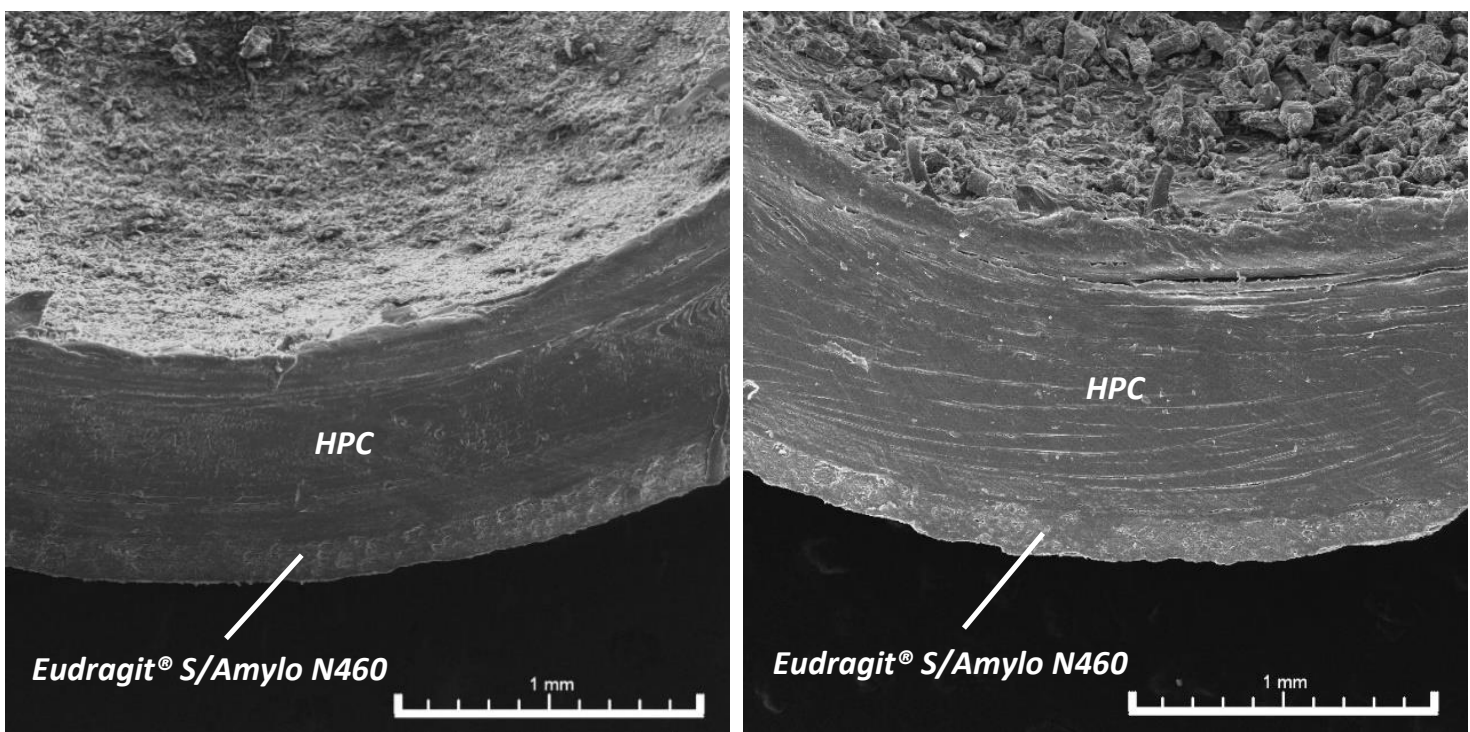

Figure 5: SEM photomicrographs of cross-sectioned HPC capsule shells coated with a Eudragit ${ }^{\circledR}$ S/Amylo N460 layer applied from a hydro-alcoholic (20\% TEC) (left) or an aqueous (49\% TEC) (right) coating formulation. 


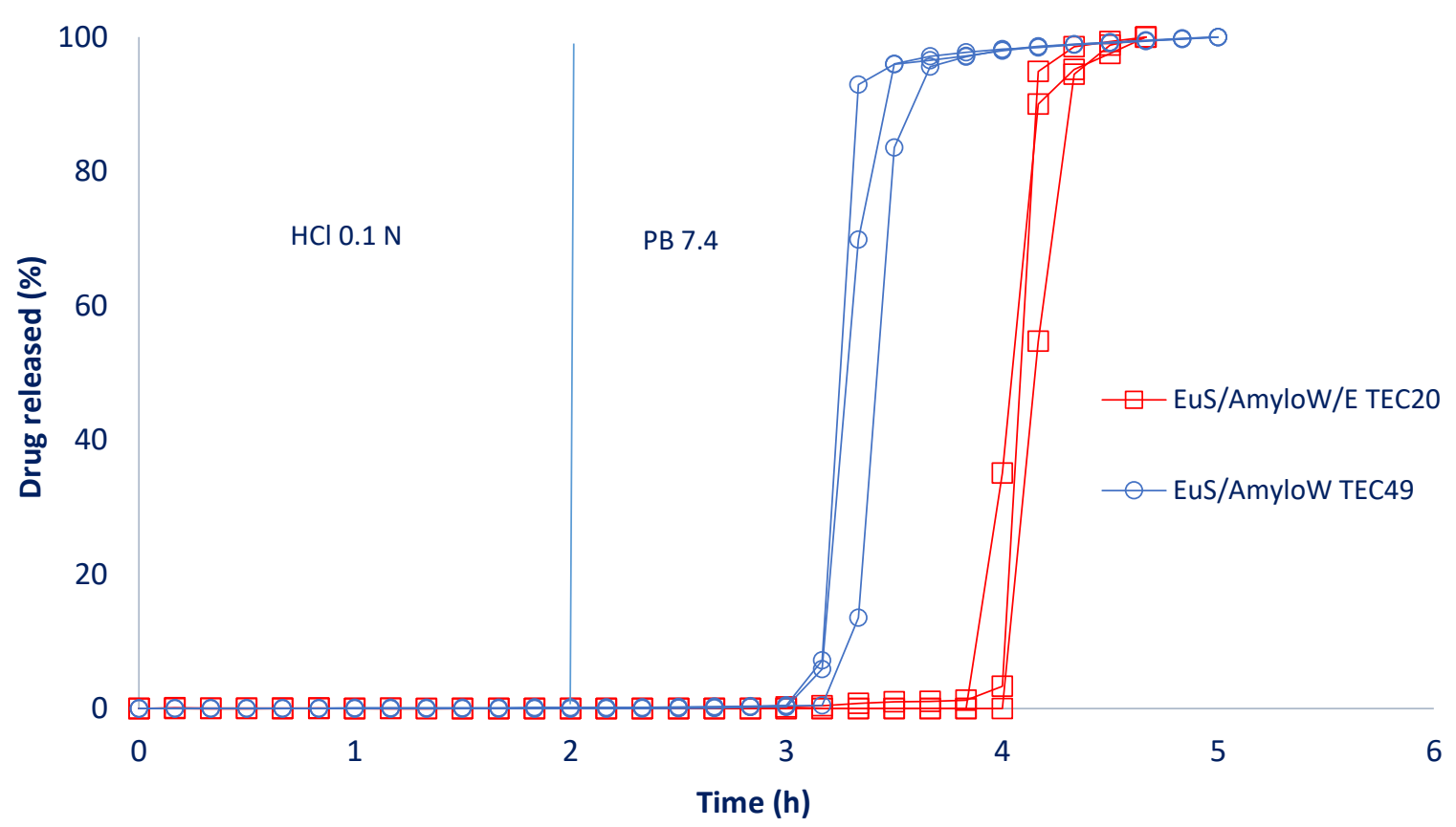

Figure 6: Paracetamol release from HPC capsules coated with a Eudragit ${ }^{\circledR}$ S/Amylo N460 layer applied from a hydro-alcoholic (20 \% TEC) or an aqueous (49\% TEC) coating formulation.

Having monitored the release behavior of the proposed formulations in "conventional" hydrochloric acid and phosphate buffer, release testing was also carried out upon exposure to simulated colonic fluid (SCF) in order to assess the possible impact of the microbiota on drug release. This fluid was obtained by inoculation of culture medium with fecal samples from IBD patients. To simulate the transit through the upper gastrointestinal tract, the dosage forms were pre-exposed to $0.1 \mathrm{~N} \mathrm{HCl}$ for $2 \mathrm{~h}$ and phosphate buffer $\mathrm{pH} 4.5$ for $2 \mathrm{~h}$. For reasons of comparison, also pure culture medium (CM) was used to monitor paracetamol release. The $\mathrm{pH}$ of both the simulated colonic fluid and pure culture medium was adjusted to 6.5, below the dissolution threshold value of the enteric polymer Eudragit ${ }^{\circledR}$ $\mathrm{S}$. The idea was to evaluate the efficacy of the backup release mechanism (polysaccharide degradation by bacterial enzymes), in case in vivo the critical $\mathrm{pH}$ would not be reached. 
As can be seen in Figure 7, paracetamol release was suppressed under conditions simulating the upper gastrointestinal tract and set on upon exposure to culture medium inoculated or not with fecal samples. Importantly, drug release was always faster in the presence of colonic bacteria compared to pure culture medium, irrespective of the TEC content and thickness of the inner HPMC layer. This clearly demonstrates the effectiveness of the backup release mechanism of enzymatic degradation in case of an insufficient raise in $\mathrm{pH}$ along the gastrointestinal tract. It has to be pointed out that paracetamol was released into the culture medium also in the absence of colonic bacteria, although the critical $\mathrm{pH}$ threshold value for Eudragit ${ }^{\circledR} \mathrm{S}$ dissolution was not reached. This can be explained by the swelling of the core formulation upon water penetration into the system: Even if the outer Eudragit ${ }^{\circledR}$ S/Amylo N460 coating does not dissolve at pH 6.5, water can slowly penetrate into the system and cause swelling of the tablet core (containing $12.5 \%$ Avicel $^{\circledR} \mathrm{PH} 101$ and $4.5 \%$ Explotab $^{\circledR}$ CLV) and of the optional HPMC inner coating layer. In simulated colonic fluid, the following rank order of drug release rates was observed with respect to the thickness of the latter: $0 \mu \mathrm{m}>200 \mu \mathrm{m}>100 \mu \mathrm{m}$. This might be explained as follows: The swelling of the uncoated core tablet is sufficient to induce crack formation in the outer Eudragit ${ }^{\circledR}$ S/Amylo N460 coating upon water penetration into the system. The presence of a relatively thin HPMC layer slows down water penetration and, thus, delays drug release. This nicely illustrates the protective effect of such a layer against premature drug release in case of failures in the outer Eudragit ${ }^{\circledR}$ S/Amylo N460 coating (please see above). However, a thick inner HPMC layer creates considerable pressure upon water penetration (the role of the swelling of the tablet core becomes less important), resulting in facilitated rupture of the outer film coating. These tendencies are particularly pronounced in the absence of colonic bacteria. Indeed, the presence of the latter introduces another release mechanism 
(degradation of the outer Eudragit ${ }^{\circledR}$ S/Amylo N460 coating), rendering crack formation due to internal pressure less important.

Furthermore, comparing Figures $7 \mathrm{a}$ and $7 \mathrm{~b}$, it becomes evident that paracetamol release was slower from formulations containing $20 \%$ TEC compared to $10 \%$ TEC in the absence of colonic bacteria. This might be explained by the fact that the higher plasticizer level leads to mechanically more stable coatings, which rupture at a later time point. Please note that in Figures $3 \mathrm{a}$ and $3 \mathrm{~b}$, the critical $\mathrm{pH}$ threshold value for Eudragit ${ }^{\circledR} \mathrm{S}$ dissolution is exceeded and, thus, the underlying release mechanism is likely different: in this case, polymer dissolution is of major importance compared to core swelling and crack formation due to internal pressure.

Figure 8 shows the drug release profiles resulting from HPC capsules filled with paracetamol powder and coated with a hydro-alcoholic Eudragit ${ }^{\circledR}$ S/Amylo N460 formulation upon exposure to $0.1 \mathrm{~N} \mathrm{HCl}$ for $2 \mathrm{~h}$, followed by $2 \mathrm{~h}$ phosphate buffer $\mathrm{pH} 4.5$ and culture medium in the presence or absence of colonic bacteria. Again, drug release was effectively suppressed under conditions simulating the upper gastrointestinal tract. Interestingly, drug release sets on in simulated colonic fluid, but not in pure culture medium. This clearly demonstrates the successful backup release mechanism in case the critical $\mathrm{pH}$ threshold for Eudragit ${ }^{\circledR} \mathrm{S}$ dissolution is not reached: The colonic bacteria induce the degradation of the starch in the outer film coating, triggering the onset of drug release. Paracetamol release was negligible in the absence of colonic bacteria, in contrast to the results observed with drug-loaded tablets (please see above). This can be explained as follows: In contrast to the coated tablets, there are numerous voids inside the capsules (which are filled with paracetamol powder). Thus, upon water penetration into the HPC 
capsule shell, the latter swells, but essentially towards the capsule filling. Consequently, no significant pressure is built up against the outer Eudragit ${ }^{\circledR}$ S/Amylo N460 coating.

Figure 9 shows the paracetamol release patterns from tablets coated with an aqueous Eudragit $^{\circledR}$ S/Amylo N460 dispersion (49\% TEC) (but without an inner HPMC coating) under the same in vitro drug release conditions. As can be seen, the colon targeting design strategy works well: Even if the critical $\mathrm{pH}$ value for the dissolution of the enteric polymer is not reached, drug release sets on under colonic conditions, due to the degradation of amylose by bacterial enzymes. It is evident that, in the absence of colonic microflora, drug release is not completely suppressed in the case of the aqueous outer film coating. This can probably be explained by the creation of pressure acting against the film coating, due to the swelling of the inner tablet core (containing $12.5 \%$ Avicel $^{\circledR}$ PH 101 and $4.5 \%$ Explotab $^{\circledR}$ CLV) (please see above), and/or the high percentage of water-soluble plasticizer. 
(a)

Hydro-alcoholic, $10 \%$ TEC

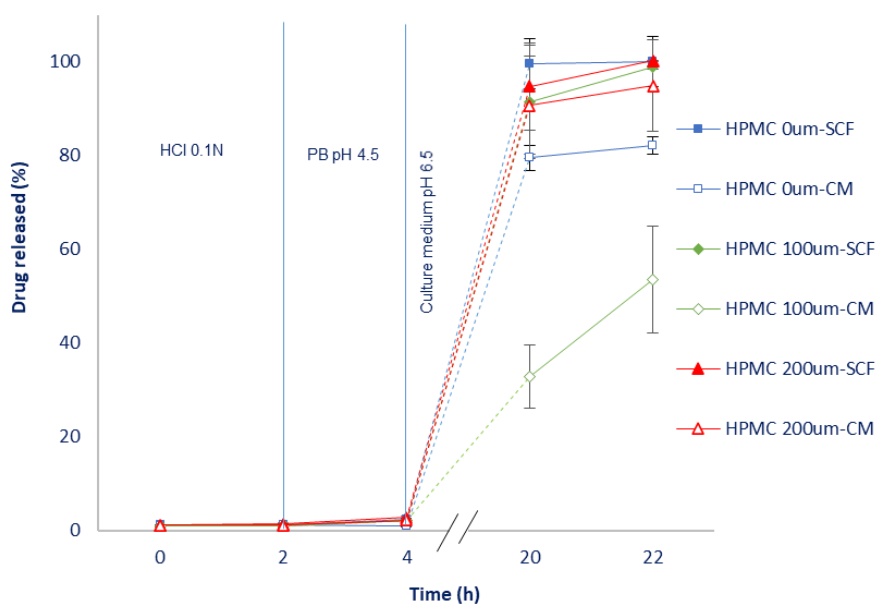

(b)

Hydro-alcoholic, $20 \%$ TEC

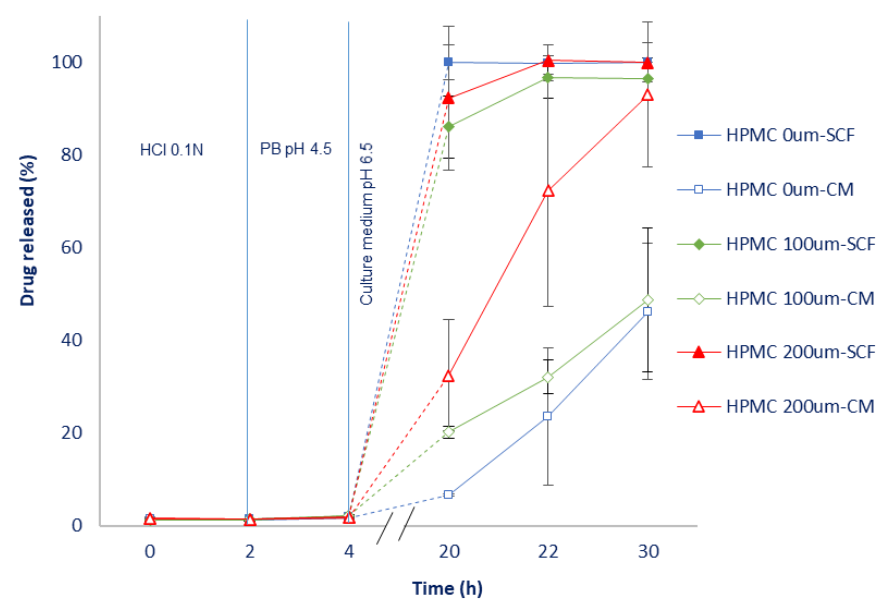

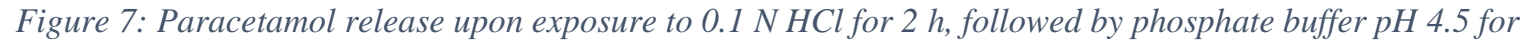
$2 \mathrm{~h}$ and pure culture medium (CM) or simulated colonic fluid (SCF) from tablets coated with an inner HPMC layer (100 or $200 \mu \mathrm{m}$ in thickness) and an outer Eudragit ${ }^{\circledR}$ S/Amylo N460 layer. The TEC content was $10 \%$ (a), or $20 \%$ (w/w, based on the dry polymer mass) (b). The outer Eudragit ${ }^{\circledR}$ S/Amylo N460 layer was applied from a hydro-alcoholic coating formulation. For reasons of comparison, also drug release from tablets without inner HPMC coating is shown.

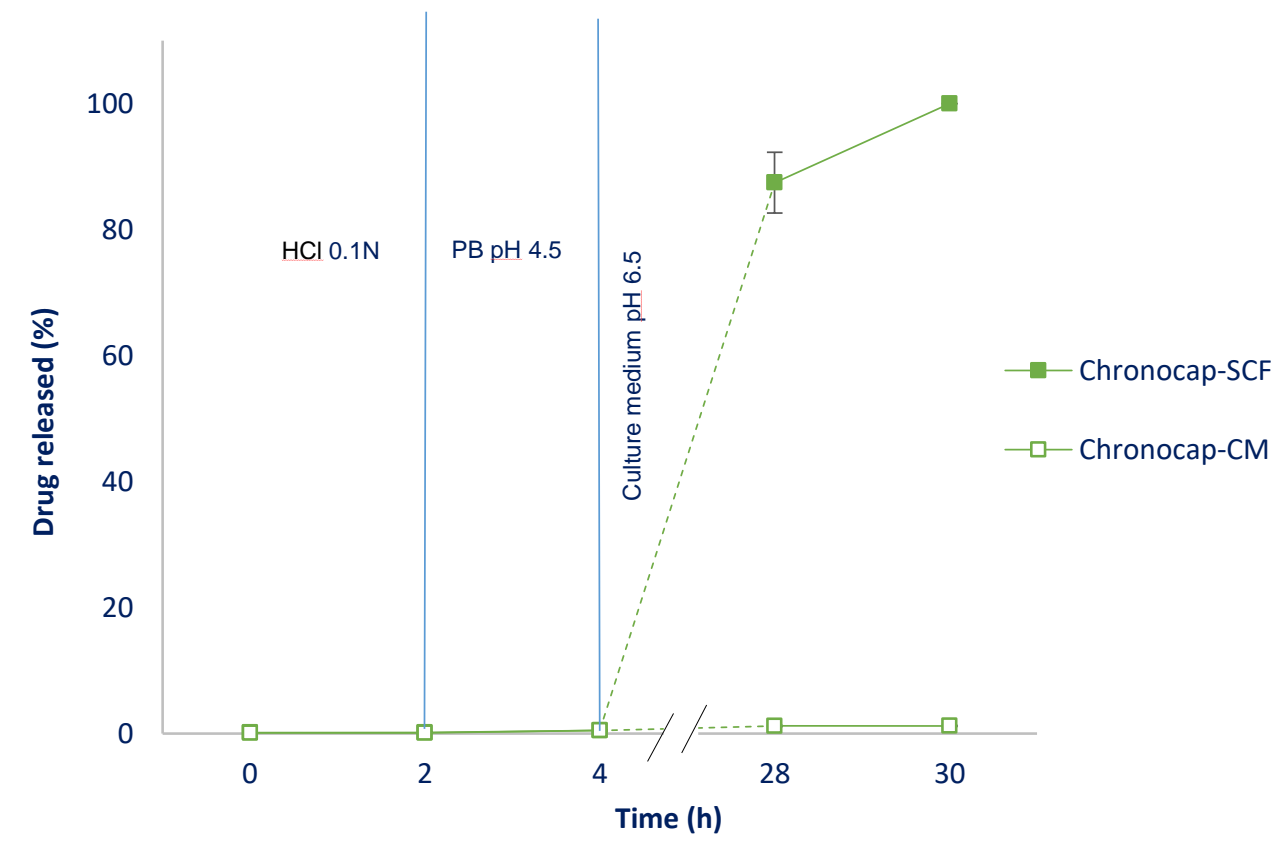

Figure 8: Paracetamol release from HPC capsules coated with a Eudragit ${ }^{\circledR}$ S/Amylo N460 layer applied

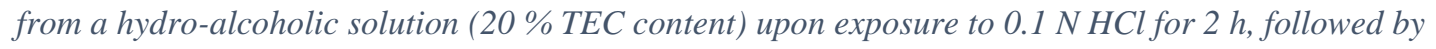
phosphate buffer pH 4.5 for $2 \mathrm{~h}$ and pure culture medium (CM) or simulated colonic fluid (SCF). 


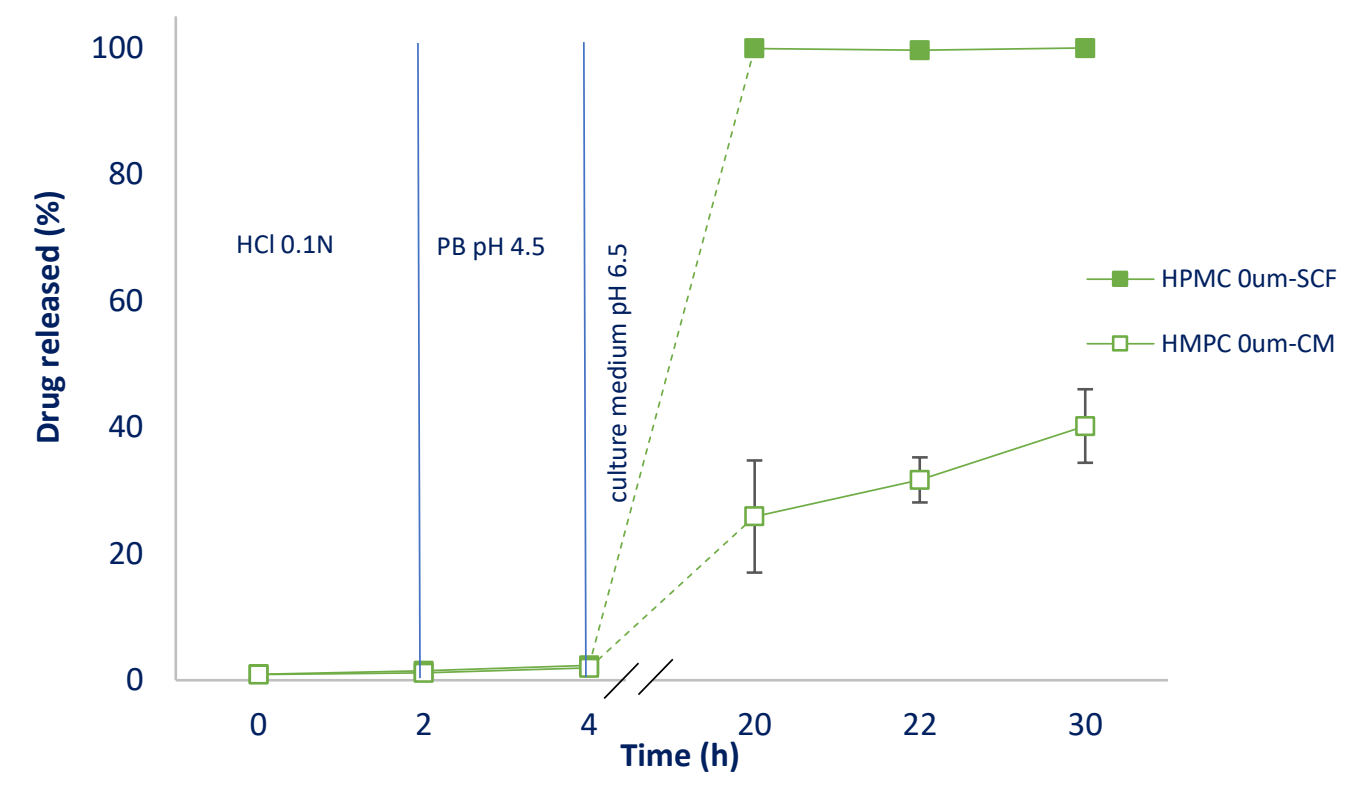

Figure 9: Paracetamol release from tablets coated with a Eudragit ${ }^{\circledR}$ S/Amylo N460 layer applied from an aqueous dispersion (49\% TEC content) upon exposure to $0.1 \mathrm{~N} \mathrm{HCl} \mathrm{for} 2 \mathrm{~h}$, followed by phosphate buffer pH 4.5 for $2 \mathrm{~h}$ and pure culture medium (CM) or simulated colonic fluid (SCF). 


\section{CONCLUSIONS}

Novel colon delivery platforms based on a combined formulation approach were designed, leveraging the intestinal transit time, enzymatic activity of the microbiota and luminal $\mathrm{pH}$. The idea is to combine an inner swellable/erodible layer, consisting of a hydrophilic cellulose ether, and a Eudragit ${ }^{\circledR}$ S-based outer enteric coating into which high-amylose starch (Amylo N460) is incorporated for selective degradation in the colonic region (as a backup drug release-triggering mechanism in case the critical $\mathrm{pH}$ threshold value of the enteric polymer is not reached in vivo).

Eudragit ${ }^{\circledR}$ S/Amylo N460 films were applied from hydro-alcoholic or aqueous formulations by spray-coating onto different drug-containing core formulations, namely: (i) tablets coated with low-viscosity HPMC (Methocel ${ }^{\circledR}$ E50), or (ii) injection-molded HPC (Klucel ${ }^{\circledR}$ LF) capsules. Both the HPMC-coated tablets and HPC capsules were per se able to defer the onset of release, as previously demonstrated.

Satisfactory physico-technological characteristics and pulsatile release patterns were observed with the coated systems. The outer films always withstood exposure to the acidic medium $(0.1 \mathrm{~N} \mathrm{HCl})$, while (as pursued) the delay brought about by dissolution of the enteric polymer was shown to be extended at simulated intestinal $\mathrm{pH}$ conditions (phosphate buffer $\mathrm{pH}$ 7.4) by the hydrophilic swellable underlying layer, irrespective of whether it was based on HPMC or HPC.

The release performance was also evaluated using simulated colonic fluid (prepared with fecal samples from IBD patients), to study the impact of possible microbial degradation of the naturally-occurring polysaccharide in the outer coating. Eudragit ${ }^{\circledR}$ S/Amylo N460 coated systems, either resulting from application of an aqueous (49 \% TEC) or hydro- 
alcoholic (20\% TEC) formulation, showed a clear dependence of the release behavior on the presence/absence of fecal bacteria.

The overall findings supported the newly proposed design concept for more reliable colon delivery, involving synergistic control of release based on multiple physiological variables.

\section{Conflicts of interests}

Given her role as Editor in Chief, Florence Siepmann had no involvement in the peer review of this article and has no access to information regarding its peer review. Full responsibility for the editorial process for this article was delegated to $<$ Name of delegated editor>. 


\section{REFERENCES}

[1] E.L. McConnell, F. Liu, A.W. Basit, Colonic Treatments and Targets: Issues and Opportunities, J. Drug Target. 17 (2009) 335-363.

https://doi.org/10.1080/10611860902839502.

[2] A. Maroni, M.D. Del Curto, L. Zema, A. Foppoli, A. Gazzaniga, Film Coatings for Oral Colon Delivery, Int. J. Pharm. 457 (2013) 372-394. https://doi.org/10.1016/j.ijpharm.2013.05.043.

[3] A. Maroni, S. Moutaharrik, L. Zema, A. Gazzaniga, Enteric Coatings for Colonic Drug Delivery: State Of The Art, Expert Opin. Drug Deliv. 14 (2017) 1027-1029. https://doi.org/10.1080/17425247.2017.1360864.

[4] D.F. Evans, G. Pye, R. Bramley, A.G. Clark, T.J. Dyson, J.D. Hardcastle, Measurement of Gastrointestinal pH Profiles in Normal Ambulant Human Subjects, Gut. 29 (1988) 1035-1041. https://doi.org/10.1136/gut.29.8.1035.

[5] M. Koziolek, M. Grimm, D. Becker, V. Iordanov, H. Zou, J. Shimizu, C. Wanke, G. Garbacz, W. Weitschies, Investigation of $\mathrm{pH}$ and Temperature Profiles in the GI Tract of Fasted Human Subjects Using the Intellicap ${ }^{\circledR}$ System, J. Pharm. Sci. 104 (2015) 2855-2863. https://doi.org/10.1002/jps.24274.

[6] M.M. Patel, A.F. Amin, Recent Trends in Microbially and/or Enzymatically Driven Colon-Specific Drug Delivery Systems, Crit. Rev. Ther. Drug Carrier Syst. 28 (2011) 489-552. https://doi.org/10.1615/CritRevTherDrugCarrierSyst.v28.i6.10.

[7] V.C. Ibekwe, F. Liu, H.M. Fadda, M.K. Khela, D.F. Evans, G.E. Parsons, A.W. Basit, An Investigation into the in Vivo Performance Variability of $\mathrm{pH}$ Responsive Polymers for Ileo-Colonic Drug Delivery Using Gamma Scintigraphy in Humans, J. Pharm. Sci. 95 (2006) 2760-2766. https://doi.org/10.1002/jps.20742. 
[8] E.L. McConnell, M.D. Short, A.W. Basit, An in Vivo Comparison of Intestinal pH and Bacteria as Physiological Trigger Mechanisms for Colonic Targeting in Man, J. Control. Release. 130 (2008) 154-160. https://doi.org/10.1016/j.jconrel.2008.05.022.

[9] V.C. Ibekwe, H.M. Fadda, E.L. McConnell, M.K. Khela, D.F. Evans, A.W. Basit, Interplay Between Intestinal pH, TRANSIT TIME and Feed Status on the in Vivo Performance of $\mathrm{pH}$ Responsive Ileo-colonic Release Systems, Pharm. Res. 25 (2008) 1828-1835. https://doi.org/10.1007/s11095-008-9580-9.

[10] R.C.A. Schellekens, F. Stellaard, D. Mitrovic, F.E. Stuurman, J.G.W. Kosterink, H.W. Frijlink, Pulsatile Drug Delivery to Ileo-colonic Segments by Structured Incorporation of Disintegrants in pH-responsive Polymer Coatings, J. Control. Release. 132 (2008) 91-98. https://doi.org/10.1016/j.jconrel.2008.08.008.

[11] R.C.A. Schellekens, F. Stellaard, G.G. Olsder, H.J. Woerdenbag, H.W. Frijlink, J.G.W. Kosterink, Oral Ileocolonic Drug Delivery by the Colopulse-System: A Bioavailability Study in Healthy Volunteers, J. Control. Release. 146 (2010) 334340. https://doi.org/10.1016/j.jconrel.2010.05.028.

[12] R.C.A. Schellekens, J.H. Baltink, E.M. Woesthuis, F. Stellaard, J.G.W. Kosterink, H.J. Woerdenbag, H.W. Frijlink, Film Coated Tablets (Colopulse Technology) for Targeted Delivery in the Lower Intestinal Tract: Influence of the Core Composition on Release Characteristics, Pharm. Dev. Technol. 17 (2012) 40-47. https://doi.org/10.3109/10837450.2010.513986.

[13] F. Liu, P. Moreno, A.W. Basit, A Novel Double-coating Approach for Improved pH-Triggered Delivery to the Ileo-Colonic Region of the Gastrointestinal Tract, Eur. J. Pharm. Biopharm. 74 (2010) 311-315. https://doi.org/10.1016/j.ejpb.2009.11.008. 
[14] F.J.O. Varum, F. Veiga, J.S. Sousa, A.W. Basit, Mucoadhesive Platforms for Targeted Delivery to the Colon, Int. J. Pharm. 420 (2011) 11-19. https://doi.org/10.1016/j.ijpharm.2011.08.006.

[15] V.C. Ibekwe, M.K. Khela, D.F. Evans, A.W. Basit, A New Concept in Colonic Drug Targeting: A Combined pH-responsive and Bacterially-triggered Drug Delivery Technology, Aliment. Pharmacol. Ther. 28 (2008) 911-916. https://doi.org/10.1111/j.1365-2036.2008.03810.x.

[16] F. Varum, A.C. Freire, H.M. Fadda, R. Bravo, A.W. Basit, A Dual pH and Microbiota-triggered Coating (Phloral ${ }^{\mathrm{TM}}$ ) for Fail-safe Colonic Drug Release, Int. J. Pharm. 583 (2020). https://doi.org/10.1016/j.ijpharm.2020.119379.

[17] F. Varum, A.C. Freire, R. Bravo, A.W. Basit, OPTICORE ${ }^{\mathrm{TM}}$, an Innovative and Accurate Colonic Targeting Technology, Int. J. Pharm. 583 (2020). https://doi.org/10.1016/j.ijpharm.2020.119372.

[18] A. Maroni, M.D. Del Curto, S. Salmaso, L. Zema, A. Melocchi, P. Caliceti, A. Gazzaniga, In Vitro and in Vivo Evaluation of an Oral Multiple-unit Formulation for Colonic Delivery of Insulin, Eur. J. Pharm. Biopharm. 108 (2016) 76-82. https://doi.org/10.1016/j.ejpb.2016.08.002.

[19] A. Melocchi, M. Uboldi, F. Briatico-Vangosa, S. Moutaharrik, M. Cerea, A. Foppoli, A. Maroni, L. Palugan, L. Zema, A. Gazzaniga, The Chronotopic ${ }^{\mathrm{TM}}$ System for Pulsatile and Colonic Delivery of Active Molecules in the Era of Precision Medicine: Feasibility by 3D Printing via Fused Deposition Modeling (FDM), Pharmaceutics. 13 (2021). https://doi.org/10.3390/pharmaceutics13050759

[20] A. Foppoli, M. Cerea, L. Palugan, L. Zema, A. Melocchi, A. Maroni, A. Gazzaniga, Evaluation of Powder-layering vs. Spray-coating Techniques in the Manufacturing 
of a Swellable/erodible Pulsatile Delivery System, Drug Dev. Ind. Pharm. 46 (2020) 1-8. https://doi.org/10.1080/03639045.2020.1788060.

[21] L. Zema, G. Loreti, E. Macchi, A. Foppoli, A. Maroni, A. Gazzaniga, InjectionMolded Capsular Device for Oral Pulsatile Release: Development of a Novel Mold, J. Pharm. Sci. 102 (2013) 489-499. https://doi.org/10.1002/jps.23371.

[22] L. Zema, G. Loreti, A. Melocchi, A. Maroni, A. Gazzaniga, Injection Molding and its Application to Drug Delivery, J. Control. Release. 159 (2012) 324-331. https://doi.org/10.1016/j.jconrel.2012.01.001.

[23] E. Macchi, L. Zema, A. Maroni, A. Gazzaniga, L.A. Felton, Enteric-coating of Pulsatile-release HPC Capsules Prepared by Injection Molding, Eur. J. Pharm. Sci. 70 (2015) 1-11. https://doi.org/10.1016/j.ejps.2014.12.020.

[24] A. Maroni, M.D. Del Curto, M. Serratoni, L. Zema, A. Foppoli, A. Gazzaniga, M.E. Sangalli, Feasibility, Stability and Release Performance of a Time-dependent Insulin Delivery System Intended for Oral Colon Release, Eur. J. Pharm. Biopharm. 72 (2009) 246-251. https://doi.org/10.1016/j.ejpb.2008.12.002.

[25] R.C. Bravo Gonzàles, T. Buser, F.J.-C. Goutte, A Delayed Release Drug Formulation, EP2659881A1, 2012.

[26] M.R. Jacobson, M. Obanni, J.N. Bemiller, Retrogradation of Starches from Different Botanical Sources, Cereal Chem. 74 (1997) 511-518. https://doi.org/10.1094/CCHEM.1997.74.5.511.

[27] Y. Karrout, C. Neut, D. Wils, F. Siepmann, L. Deremaux, M.P. Flament, L. Dubreuil, P. Desreumaux, J. Siepmann, Peas Starch-based Film Coatings for Sitespecific Drug Delivery to the Colon, J. Appl. Polym. Sci. 119 (2011) 1176-1184. https://doi.org/10.1002/app.32802. 
[28] Y. Karrout, L. Dubuquoy, C. Piveteau, F. Siepmann, E. Moussa, D. Wils, T. Beghyn, C. Neut, M.P. Flament, L. Guerin-Deremaux, L. Dubreuil, B. Deprez, P. Desreumaux, J. Siepmann, In vivo Efficacy of Microbiota-sensitive Coatings for Colon Targeting: A Promising Tool for IBD Therapy, J. Control. Release. 197 (2015) 121-130. https://doi.org/10.1016/j.jconrel.2014.11.006.

[29] F. Casati, A. Melocchi, S. Moutaharrik, M. Uboldi, A. Foppoli, A. Maroni, L. Zema, C. Neut, F. Siepmann, J. Siepmann, A. Gazzaniga, Injection Molded Capsules for Colon Delivery Combining Time-controlled and Enzyme-triggered Approaches, Int. J. Mol. Sci. 21 (2020). https://doi.org/10.3390/ijms21061917.

[30] Y. Karrout, C. Neut, D. Wils, F. Siepmann, L. Deremaux, M.P. Flament, L. Dubreuil, P. Desreumaux, J. Siepmann, Novel Polymeric Film Coatings for Colon Targeting: Drug Release from Coated Pellets, Eur. J. Pharm. Sci. 37 (2009) 427433. https://doi.org/10.1016/j.ejps.2009.03.014.

[31] Y. Benzine, F. Siepmann, C. Neut, F. Danede, J.F. Willart, J. Siepmann, Y. Karrout, Hot Melt Extruded Polysaccharide Blends for Controlled Drug Delivery, J. Drug Deliv. Sci. Technol. 54 (2019) 101317. https://doi.org/10.1016/j.jddst.2019.101317.

[32] A. Goyanes, J. Wang, A. Buanz, R. Martínez-Pacheco, R. Telford, S. Gaisford, A.W. Basit, 3D Printing of Medicines: Engineering Novel Oral Devices with Unique Design and Drug Release Characteristics, Mol. Pharm. 12 (2015) 40774084. https://doi.org/10.1021/acs.molpharmaceut.5b00510.

[33] A. Foppoli, A. Maroni, S. Moutaharrik, A. Melocchi, L. Zema, L. Palugan, M. Cerea, A. Gazzaniga, In vitro and Human Pharmacoscintigraphic Evaluation of an Oral 5-ASA Delivery System for Colonic Release, Int. J. Pharm. 572 (2019). https://doi.org/10.1016/j.ijpharm.2019.118723. 
[34] A. Foppoli, A. Maroni, L. Palugan, L. Zema, S. Moutaharrik, A. Melocchi, M. Cerea, A. Gazzaniga, Erodible Coatings Based on HPMC and Cellulase for Oral Time-controlled Release of Drugs, Int. J. Pharm. 585 (2020) 119425. https://doi.org/10.1016/j.ijpharm.2020.119425.

[35] J. Siepmann, F. Siepmann, Stability of Aqueous Polymeric Controlled Release Film Coatings, Int. J. Pharm. 457 (2013) 437-445. https://doi.org/10.1016/j.ijpharm.2013.10.010. 